\title{
Looking Back at the Evolution of James Cone's Theological Anthropology: A Brief Commentary
}

\author{
Sekhmet Ra Em Kht Maat
}

Department of History, Political Science, Geography and Africana Studies, Tennessee State University, Nashville, TN 37209, USA; cmcalli1@tnstate.edu

Received: 30 July 2019; Accepted: 25 October 2019; Published: 28 October 2019

\begin{abstract}
Reverend Dr. James Hal Cone has unquestionably been a key architect in defining Black liberation theology. Trained in the Western theological tradition at Garrett Theological Seminary, Cone became an expert on the theology of Twentieth-century Swiss-German theologian Karl Barth. Cone's study of Barth led to his 1965 doctoral dissertation, "The Doctrine of Man in the Theology of Karl Barth," where he critically examined Barth's Epistle to the Romans and Church Dogmatics. His contemporaries and more recent African American theologians and religious scholars have questioned the extent to which Karl Barth's ideas shaped Cone's Black theology. The purpose of this brief commentary is to review the major ideas in "The Doctrine of Man" and Black Theology and Black Power, his first book, to explore which theological concepts Cone borrows from Barth, if any, and how Cone utilizes them within his articulation of a Black theological anthropology and Black liberation theology.
\end{abstract}

Keywords: James Hal Cone; African American theological anthropology; Black Theology; Black Liberation Theology; Karl Barth

\section{Introduction}

It is without question that ancestor Reverend Dr. James Hal Cone has been one of the key architects in defining and shaping the Black liberation theological tradition. Although nineteenth-century African Methodist Episcopal bishop Henry McNeil Turner had already identified that a people's creator must be a reflection of themselves, and therefore, the God of his people must be Black, Cone's writings were one of the first academic texts to explore the relationship between the African American human condition and the working of God in the world, or in other words a Black theological anthropology (Carter 2014, pp.177-78; Cone 1984). Cone is undoubtedly one of the most influential and significant theologians of the twentieth and early twenty-first centuries.

Beginning with his first publication, Black Theology and Black Power (Cone 1969) up to the release of his autobiographical Said I Wasn't Gonna Tell Nobody: The Making of a Black Theologian (Cone 2018) before his passing, Cone consistently and unapologetically declared that according to scripture, God has always identified with conditions and lived realities of the stranger, the outsider, and the poor. So, for Cone, to be Christian, one must see God in the African American human condition and work to bring about social, political, and economic freedom for African Americans who suffer from white supremacy in the American empire. But his theological ideas evolved to ultimately include the liberation of all who are oppressed by white supremacy, capitalism, patriarchy, and heterosexism, and even paralleling and informing liberation theological developments throughout the world. In an obituary published in The Washington Post, Cone's former student, Womanist theologian Reverend Dr. Kelly Brown Douglas, attested to the fact that he "centered the Gospels on racial justice and later on the struggles for gender and class equality" (Smith 2018). Cone's ideas about liberation theology ultimately opened 
the door for the development of Womanist theology, and even more recently, African American queer theological considerations.

Cone's theological development is located within his exposure to the Western theological tradition. During the height of the Civil Rights Movement, Cone attended Northwestern University's Garrett Evangelical Theological Seminary, where he received his graduate education. The writings of early twentieth-century Swiss-German theologian Karl Barth, among other white theologians, comprised the all-white curriculum (Cone 1981). Completing a master's thesis on Satan in Barth's theology and a doctoral dissertation, "The Doctrine of Man in the Theology of Karl Barth" (Cone 1965), Cone became an expert on Barth. But his mastery was only the means for successful matriculation through an institution in which faculty were unwilling to discuss the relationship between race, racism, and theology. He writes:

I realized that Garrett would not be the best context for expressing my deepest feelings about racism, if I expected to receive a Ph.D. degree from that institution. That was why I did not raise the racism issue as a theological problem, and also why I decided to write a dissertation on Karl Barth's anthropology rather than on some issue in the black community. (Cone 1981, p. 163)

Certain African American theologians and religious scholars have questioned the influence of the Western theological tradition in Cone's theological anthropology. In 1969, African American theologians Charles Long and Gayraud Wilmore, among others, were the first to question the extent to which Cone's concepts in Black Theology and Black Power were borrowed from Barth, Paul Tillich, and other white theologians (Cone 1981). For these earlier Black theologians who also shaped the field of Black theology, Cone's utilization of white theological concepts was antithetical to the lived experiences of Black folks and their faith practices. How could the theologies written by Barth, Tillich, and others speak to the liberation of Back people, they asked? (Cone 1981). By 1975, Cone's contemporary, theologian J. Deotis Roberts, maintained in "Black Theological Ethics: A Bibliographical Essay," that Cone indeed, "inaugurated the black theology movement" (Roberts 1975, p. 88). But like Roberts' colleagues half a decade prior proposed, Cone, for Roberts, was "too Barthian" (p. 72); Cone's sources did not come from traditional African and African American religious culture and spiritual philosophy (p. 72). However, other theologians writing during the 1970s applauded Cone's use of Barth. Scholar Edmund Hill, in "Black Theology," highlighted the fact that Cone made scripture relevant and purposeful for contemporary communities, a clear influence from Barth (Hill 1973). Theologian G. Clarke Chapman situated Cone directly within the Western theological tradition, suggesting that Cone was not unlike any other Western and American theologian who borrowed, reinvented, and repurposed their predecessors' theological ideas. In fact, the process of reinventing theology is the art of maintaining and expanding the theological tradition (Chapman 1972, p.149).

The late twentieth and early twenty-first century brought about renewed interest in thinking through Cone's ideas. Several religious scholars continued with Long, Wilmore, and Robert's line of reasoning around Barth's influence on Cone and claimed that Cone's Black theology was a "critical appropriation" of Barth's theology (Carr 2011), while other writers looked for complementarity between Cone and Barth's theologies (Mitchell 1999). On the other hand, African American theologian Victor Anderson in his Beyond Ontological Blackness suggested that Cone made a "radical disjunction of Black theology from European sources ... and their evangelical roots" (Anderson 1995, p. 91). The most recent discussion continues with Anderson's perspective and challenges the claim that Cone appropriated Barth's theological ideas and concepts, arguing instead that Cone's theological anthropology challenged Barth's ideas, as outlined in Epistle to the Romans and Church Dogmatics (Carter 2014, pp. 178-79).

In celebration of the life of James Cone and his unwavering life-long commitment to the liberation of Black people, the purpose of this commentary is to reflect on the development of Cone's early ideas that blossomed into his Black theological anthropology. I come to this reflection, which in fact began during a seminary course on Karl Barth, seeking to tease out the trajectory of Cone's early theological 
ideas. In doing so, this brief article examines how Cone's "The Doctrine of Man" unpacks Barth's theological anthropology, as written in the Epistle to the Romans and Church Dogmatics. It then outlines how Cone reconsiders, reframes, and reconstructs Barth's ideas in Black Theology and Black Power. The major questions this work asks are: Does Cone borrow conceptually from Barth? If so, how does Cone strategically utilize Barth's ideas in the development of a Black theological anthropology? Is Cone's Black theology, Barthian?

\section{Cone on Barth}

In "The Doctrine of Man in the Theology of Karl Barth", Cone explores Barth's conception of the human being. The purpose of the dissertation is to not only investigate Barth's doctrine of man in Church Dogmatics, III/2 but also trace the evolution of Barth's thinking about an anthropology, beginning with Epistle to the Romans. Cone explains the particular liberal theological and historical backdrop to which Barth is responding. Cone writes:

In liberal Christianity, it is not God who determines the religious relationship; it is [thinking] man [who relies on reason to know God]. We must not forget that Barth began his career as a liberal theologian. The first World War [however] shattered his hope of the Kingdom of God on earth. In due time Barth was led from his anthropocentric conception of Christianity to a thorough-going theocentric conception. (Cone 1965, p. 3)

This historical backdrop is important because it explains the importance of the work for Barth. Teasing out a theological anthropology was in direct response to anxieties that liberal theology had not resolved. In fact, these anxieties culminated in the European war of 1914, and Barth sought to explain the meaning of human experience amid this chaos and in response to the state of human affairs in which Barth found himself.

It is within the Epistle, then, that Cone begins his investigation of Barth because, within this text, Barth comes to a new conclusion. He dispenses with the liberal theological idea that human beings and their political activism against injustice can, in fact, create a social world that is in line with the will of God. In fact, Cone states that Barth concludes that thinking about the human condition in line with liberal theology is the work of the Antichrist (Cone 1965). Barth's radical turn away from liberal theology, then, is the source of his anthropology, one that is centered in the relationship between God, humanity, and the Kingdom of God. Barth no longer believed in humanity. He "was led from trust in man to complete trust in God alone" (p. 8). Barth, therefore, outlines his theology of humanity in direct response to the impossibility of humanity to bring about the Kingdom of God on earth. What is Barth's conception of God as Cone sees it?

Cone explains that Barth defines God to be completely different and distinct from human existence. God and humanity are of two substances, an idea that Barth owes to nineteenth-century Danish philosopher Soren Kierkegaard, who defined the categories between God and humans as of "infinite qualitative distinction" (p. 8). In line with Kierkegaard, Barth, therefore, views God not only as the source of spiritual and physical realities but as a transcendent essence (p. 11). Human beings, on the other hand, are designed by God and are simultaneously an expression of God, but human beings are depraved and overtaken by their egos, through which each human being creates aspects of the material world. Further explaining Barth's distinctions, Cone writes, "of man is pride. Man wants to become independent; he desires to ignore the 'infinite qualitative difference' between God, the Creator, and man, the creature. Against man's assertion of his pride, Barth sees the everlasting No of God ... and this means that the whole world is doomed to destruction" (p. 14). Cone continues his assessment writing that, "[the human being] realizes that [he/she] is nothing but, as it were, a filthy rag before a righteous God" (ibid). In the final analysis, here, Cone identifies that human beings, for Barth, are neither God nor divine in any way. Human beings are sinners.

Barth also grounds his anthropology in the Word of God. To flesh out this concept, Cone examines Barth's "Doctrine of Creation" in Church Dogmatics III/2. In doing so, Cone explains that human beings 
cannot perceive their purpose because of their depraved condition, according to Barth, because of the distinct quality of God and the nature of humanity. But it is through the Word of God, Jesus, that the creator sent to earth in flesh, that human beings can begin to know themselves beyond their ego. Cone agrees that this point is Barth's defining contribution and explains his agreement with Barth in this way; because of its significance, I will quote the passage in full. Cone writes:

To know the divine attitude toward man is to know the particular man Jesus Christ and to know man is to know the human nature of Jesus. To be sure, Jesus does become what we are [human], but he does not do what we do [sin], and so he is certainly not now what we are [sinners]. He alone is primarily elected; he alone is the receiver and the bestower of grace at the same time, whereas man, in general, can only be one who has received grace. But when it is said that human nature is one thing in Him, it is not corrupted by sin ... He held his ground against temptation (p. 53).

Human beings, on the one hand, are in an appositional relationship with God, a God who sends Christ to earth to show humanity their ego-filled, sinful state, an orientation among human beings that is distinct from Jesus, the Word in flesh. On the other hand, however, and most importantly, Christ is grace. It is through Christ as grace that humans can see their true humanity.

It is in that historical moment, when God came in flesh, that God gave purpose to and meaning for humanity. God is, therefore, preparing humanity for the coming of the final Kingdom of God. God, however, revealed in Jesus, is not bound by that historical event in which Jesus walked the earth. About this point, Cone writes that "Barth goes on to stress that both the time after and the time before the Incarnation was also his time" (p. 118). God, through Jesus, is forever alive in the world through God's grace. But human beings, however, are still sinners regardless of time, space, and history.

\section{Moving beyond Barth's "Doctrine of Man"}

In Black Theology and Black Power, Cone seeks to reinterpret the human experience in relation to God during one of the most racist and violent moments in America. While writing in the summer of 1968, Cone was keenly aware of African Americans' centuries long-struggle for freedom, equality, and integration, with its most contemporary expression in the work of the Civil Rights Movement. Cone had been a staunch supporter of Reverend Dr. Martin Luther King, Jr. and his non-violent activist strategies for full integration (Cone 2018, p. 74).

On the other hand, by 1966, Stokely Carmichael (Kwame Ture) and other Black power revolutionaries echoed Malcolm $X$ after his assassination, calling for African Americans to rethink their desire for integration into the white middle class. Middle-class values for these thinkers were individualistic, anti-human, and anti-Black, leaving most African Americans poor, disenfranchised, and on the periphery of society with minimal opportunities to actualize their full human potential. It was of great concern for many of these radical thinkers at the time to align themselves with the larger pan African and "Third World" revolutionary movements that sought to challenge colonial and neo-colonial economic, political, and social infrastructures. Cone was inspired by this philosophy and struggled to come to terms with what liberation looked like. He writes, "For me, the burning theological question was, how can I reconcile Christianity and Black Power, Martin Luther King Jr.'s idea of nonviolence and Malcolm X's 'by any means necessary' philosophy? The writing of Black Theology and Black Power was the beginning of my search for a resolution of that dilemma" (Cone 1997, p. viii).

It is possible, then, Barth's impetus for writing the Epistle to the Romans was an example for Cone about the possibilities of using theology to respond to an injustice. Barth and then Cone, though responding to particular contexts, are both prompted to write their theologies out of sociological and theological imperatives. Barth is writing in response to liberal theology and dystopian possibilities because of the war; he seeks to explain how God relates to a humanity that does not seem to know God. Similarly, Cone is impassioned to write about the relationship between God and African American 
humanity because the latter struggles under the weight of a racism that is upheld by a racist Christian theology. Both are seeking to create a theology that challenges the Antichrist. This may be the major influence Barth has on Cone?

In Black Theology and Black Power, Cone does write about God's revelation. In the "Doctrine of Man in the Anthropology of Karl Barth," Cone explains Barth's use of Kierkegaard's infinite qualitative distinction to describe the differences between God and humanity. Cone does not initially challenge Barth on this point in thinking about the creation of a Black theological anthropology. For in Black Theology and Black Power, he does stand firm on the fact, similar to Barth, that humanity cannot know itself without placing Jesus at the center of one's theology, and humanity cannot know God without God revealing itself in Christ. Cone writes that Jesus "is the Revelation, the special disclosure of God to man, revealing who God is and what his purpose for man is" (Cone 1965, p. 166).

The particulars of God's revelation in Christ is where Cone decisively breaks from Barth. In Cone's dissertation, he explains that Barth believes that human beings are unequivocally sinners, as discussed in previous sections. In fact, God reveals itself in Christ among the sinful so that human beings can partake in God's grace in preparation for the coming of the Kingdom of God. But in doing so, Christ becomes a human being and becomes the "fellow" of every other human being, although both sin and the power of evil still remain in the world. In creating an anthropology, Cone releases Barth and turns to the New Testament to clarify what God's revelation means for humanity. In Black Theology and Black Power, he writes:

According to the New Testament, Jesus is the man for others who views his existence as inextricably tied to other men to the degree that his own Person is inexplicable apart from others. The others, of course, refer to all men, especially the oppressed, the unwanted of society, the "sinners." He is God Himself coming into the very depths of human existence for the sole purpose of striking off the chains of slavery, thereby freeing man from the ungodly principalities and powers that hinder his relationship from God . (Cone, p. 35)

Although Cone, similar to Barth, finds that Christ emerges among sinners, Cone remaps the meaning of the sinful nature of man in relation to the revelation of God. The revelation of God in Christ for Cone means that Christ came among "sinners," those who are abused by society, which is the power of evil and, therefore, the Antichrist, as the example of how contemporary society must seek to overcome these injustices and the Antichrist. Here, sin is the "loss of identity" (p. 198). The systems of oppression and those who do not resist this system and the oppression of others are sinners. Who is defined as a sinner within Cone's work is not borrowed from Barth.

\section{Cone and an African American-Centered Theological Anthropology}

Cone's final break with Barth is in laying claim to a specific African American relationship to God. If the revelation of God in Christ occurs among the oppressed, then God is working through African Americans and other activists who, during the writings of Black Theology and Black Power, are actively mobilizing, by any means necessary, for freedom against oppression. Jesus, then, is no longer confined to the New Testament, nor that particular historical moment. Cone returns to the Hebrew Bible and finds that God, even before the revelation in Christ, is working to alleviate oppression, and so too, then must God be working in this way among African Americans who are oppressed. The fundamental question that Cone's work proposes in relation to an African American theological anthropology, then, is, "what does Christ mean for the oppressed blacks of the land?" (p. 156). He responds in A Black Theology of Liberation (Cone 2010) that, "the sole purpose of God in our theology is to illuminate the black condition so that black people can see that their liberation is the manifestation of [God's] activity. We believe that we can learn more about God and, therefore, about man, by examining black people as they get ready to do their thing ... " (p. 90). Unlike Barth, who scripts a theocentric anthropology, Cone calls for an anthropocentric theological anthropology with the Black struggle for freedom from oppression at the center. 
God and Jesus are integral to the process of African Americans being in communion with God, according to Cone. But the process is no longer attached to their natural, ego-based subject position as a sinner, which began with the fall of humanity. This point is another decisive break from Barth. For Cone, African Americans can only know themselves, know God, by cleaving to the best methods that African Americans have always used within the long struggle for freedom and equality to challenge their oppressors, or in a word, the Antichrist. Liberating activities among African Americans are God at work in the world. In his autobiography, Said I Wasn't Gonna Tell Nobody, Cone reflects on his theological break from both Kierkegaard and Barth's ideas of God's revelation. Telling the story of his colleague's criticism of this movement, Cone writes, "as he saw it, following Barth who himself was following the great Danish theologian Soren Kierkegaard, God's revelation is "wholly other," never ever identified with the ideas and actions of human beings (2018, p. 10). But for Cone, during the writing of his anthropology, the time was ripe for Black Power. For did not Jesus remind the Jewish people of the best of their traditions amid Roman occupation? So too did Cone in writing a Black theological anthropology.

\section{Conclusions}

In The Oxford Handbook on African American Theology (2014), African American religious scholar J. Kameron Carter provides his perspective on the extent to which Cone relies upon Barth's conceptions to think about the relationship between God and humanity. Tracing the historical development of African American theological anthropology, Carter positions Cone as the innovator of this field of study. For Carter, Cone's interpretation of the human condition in relation to God cannot be understood without considering his dissertation, "The Doctrine of Man in the Theology of Karl Barth". Nonetheless, this theological backdrop does not in any way diminish Cone's fidelity to Black power and the long-arch of African Americans' struggle for liberation. Carter concludes:

Cone was not seeking to do "white theology" in (Barthian) blackface. Rather, he was starting to develop a style of theology specific to this early moment of African American theological anthropology and to deal with the problem and inventions of man ... .[As] Frantz Fanon developed an appositional relationship to psychoanalytic theory (particularly, to Jacques Lacan) to address the problem of the colonization of psychic space, so too Cone and early African American theological anthropology was forging an appositional relationship to theology itself in order to conceive and reframe the task of theology itself under conditions of civil rights, Black Power, and decolonization efforts around the world. (pp. 178-79)

In Carter's estimation, Cone used Barth's theology only as a tool to develop his own into one that was reflective of African American suffering and grounded in liberation, eventually challenging and therefore turning Barth's doctrine on its head.

Funding: This research received no external funding.

Conflicts of Interest: The author declares no conflict of interest.

\section{References}

Anderson, Victor. 1995. Beyond Ontological Blackness: An Essay on Religious and Cultural Criticism. New York: Continuum.

Carr, Raymond. 2011. Barth and Cone in Dialogue on Revelation and Freedom: An Analysis of James Cone's Critical Appropriation of "Barthian" Theology. Unpublished dissertation, Graduate Theological Union, Berkeley, CA, USA.

Carter, Kameron J. 2014. Humanity in African American Theology. In The Oxford Handbook of American Theology. Edited by Katie G. Cannon and Anthony B. Pinn. New York: Oxford, pp. 174-84.

Chapman, G. Clarke. 1972. American Theology in Black: James H. Cone. Cross Currents 33: 139-57.

Cone, James H. 1965. The Doctrine of Man in the Anthropology of Karl Barth. Unpublished dissertation, Northwestern University Garrett Theological Seminary, Evanston, IL, USA. 
Cone, James H. 1969. Black Theology and Black Power. New York: Seabury.

Cone, James H. 1981. The Gospel and the Liberation of the Poor. The Christian Century, February 18, $162-66$.

Cone, James H. 1984. For My People: Black Theology and the Black Church. Maryknoll: Orbis.

Cone, James H. 1997. Black Theology and Black Power. Maryknoll: Orbis.

Cone, James H. 2010. A Black Theology of Liberation. Maryknoll: Orbis.

Cone, James H. 2018. Said I Wasn't Gonna Tell Nobody: The Making of a Black Theologian. New York: Orbis.

Hill, Edmund. 1973. Black Theology. New Blackfriars 54: 244-53. [CrossRef]

Mitchell, Beverly Eileen. 1999. Karl Barth and James Cone: The Question of Liberative Faith and Ideology. Unpublished dissertation, Boston College, Chestnut Hill, MA, USA.

Roberts, J. Deotis. 1975. Black Theological Ethics: A Bibliographical Essay. The Journal of Religious Ethics 3: 69-71. Smith, Harrison. 2018. James H. Cone, Founder of Black Liberation Theology, Dies at 79. Washington Post, May 4.

(C) 2019 by the author. Licensee MDPI, Basel, Switzerland. This article is an open access article distributed under the terms and conditions of the Creative Commons Attribution (CC BY) license (http://creativecommons.org/licenses/by/4.0/). 